\title{
Joshua A. Fishman: A Scholar of Unfathomable Influence
}

Nancy H. Hornberger

University of Pennsylvania, nancyh@gse.upenn.edu

Follow this and additional works at: https://repository.upenn.edu/gse_pubs

Part of the Bilingual, Multilingual, and Multicultural Education Commons, Curriculum and Social Inquiry Commons, Educational Assessment, Evaluation, and Research Commons, Educational Psychology Commons, Language and Literacy Education Commons, Social and Philosophical Foundations of Education Commons, and the Sociology Commons

\section{Recommended Citation}

Hornberger, N. H. (2017). Joshua A. Fishman: A Scholar of Unfathomable Influence. International Journal of the Sociology of Language, 243 17-28. http://dx.doi.org/10.1515/ijsl-2016-0043

This paper is posted at ScholarlyCommons. https://repository.upenn.edu/gse_pubs/475

For more information, please contact repository@pobox.upenn.edu. 


\title{
Joshua A. Fishman: A Scholar of Unfathomable Influence
}

\begin{abstract}
In personal tribute to Joshua A. Fishman, I tell a few stories about this remarkable scholar as I got to know him - a glimpse of the person behind the great ideas that have so powerfully shaped our thinking. My many vivid memories of things Fishman said or wrote in my personal encounters with him - often pithy one-liners - are testimony to the power of his mind and voice, his spirit and soul. From my first year of Ph.D. study when I took his course Sociology of Bilingual Education at the 1980 Linguistic Society of America Summer Institute at the University of New Mexico in Albuquerque, through our interactions over the succeeding decades at conferences and talks, in personal visits and interviews, and around publications he invited me to write or vice versa, Fishman's influence on my own academic career was enduring and profound. My turn to honor Professor Fishman for all he did for scholarship, globally, and for me, personally, came in the intergenerational symposium we organized for him at Penn in honor of his 80th birthday in 2006. My hope is that these personal stories begin to convey the intellectual giant Joshua A. Fishman was.
\end{abstract}

\section{Keywords}

biliteracy, language and ethnicity, language loyalty, language planning, language revitalization

Disciplines

Bilingual, Multilingual, and Multicultural Education | Curriculum and Social Inquiry | Education | Educational Assessment, Evaluation, and Research | Educational Psychology | Language and Literacy Education | Social and Philosophical Foundations of Education | Sociology 


\section{Nancy H. Hornberger* \\ Joshua A. Fishman: a scholar of unfathomable influence}

DOI 10.1515/ijsl-2016-0043

Abstract: In personal tribute to Joshua A. Fishman, I tell a few stories about this remarkable scholar as I got to know him - a glimpse of the person behind the great ideas that have so powerfully shaped our thinking. My many vivid memories of things Fishman said or wrote in my personal encounters with him often pithy one-liners - are testimony to the power of his mind and voice, his spirit and soul. From my first year of Ph.D. study when I took his course Sociology of Bilingual Education at the 1980 Linguistic Society of America Summer Institute at the University of New Mexico in Albuquerque, through our interactions over the succeeding decades at conferences and talks, in personal visits and interviews, and around publications he invited me to write or vice versa, Fishman's influence on my own academic career was enduring and profound. My turn to honor Professor Fishman for all he did for scholarship, globally, and for me, personally, came in the intergenerational symposium we organized for him at Penn in honor of his 80th birthday in 2006. My hope is that these personal stories begin to convey the intellectual giant Joshua A. Fishman was.

Keywords: biliteracy, language and ethnicity, language loyalty, language planning, language revitalization

Joshua A. Fishman is a scholar of unfathomable influence. I recently encountered another evidence of this in Awad Ibrahim's forthcoming Encyclopedia of language and education entry (Ibrahim, forthcoming), where in discussing the intersection of hybridity, migration/flow and language, he provides a wonderful tribute to Fishman's forerunning work on language as symbol of ethnicity - as producer and product of identity (Fishman 1977). Reading Ibrahim's essay brought to mind for me (Fishman et al., 1985) book, The rise and fall of the ethnic revival, where he talks about language as a part of, an index of, and a symbol of ethnicity and culture (Fishman et al. 1985: xi, 505) and about ethnicity as "peopleness relatedness" (Fishman et al. 1985: 46). Elsewhere, he elaborates

*Corresponding author: Nancy H. Hornberger, Graduate School of Education, University of Pennsylvania, Philadelphia, PA, USA, E-mail: nancyh@upenn.edu 
on "the sense of being part of a particular people, doing the things that this people traditionally does, and therefore, of knowing (appreciating, sensing, feeling, intuiting) things this people claims to know" (Fishman 1982: 7), the particular being, doing, knowing associated with "one's own kind... who are we? from where do we come? what is special about us?” (Fishman et al. 1985: 4) words of insight and eloquence I never tire of sharing with my students.

As a scholar (and indeed in life), I have always loved hearing stories about the person behind the great ideas that powerfully shape our thinking, so I want to tell you a few stories about Joshua Fishman the person as I got to know him, using also some of his own words ${ }^{1}$, accompanied by a few photos. It is remarkable that I have so many very vivid memories of things Fishman said or wrote in my personal encounters with him - often very pithy one-liners that have stayed with me. Such is/was the power of his mind and voice, his spirit and soul. I know I can only begin to convey some of the intellectual giant he was through these stories and that they are inevitably biased by my own interpretation. But here goes.

As I prepared these remarks, the refrain that kept going through my head as I reflected on Fishman the scholar and Fishman the warm and generous human being was the great American spiritual, He's got the whole world in his hands, adapted as he's got the whole world in his head... he's got the whole world in his heart.

I first met Professor Fishman in the summer of 1980 when in my first year of Ph.D. study, I took his course on the Sociology of Bilingual Education at the Linguistic Society of America Summer Institute at the University of New Mexico in Albuquerque - a course that had life-changing impact for me. I wrote to him about one piece of that 30 years later when I was unable to attend in person as a delegation from the Royal Academy of the Basque Language came to his home in New York City to grant him honorary membership. I wrote at that time:

Warmest congratulations to you on this day of great honor as you are recognized by our Basque colleagues who have traveled far to see you. I am very much with you in spirit, as you are - always - very much with me in my life and work. Just this week in my graduatelevel Language Diversity and Education class, we read your 1982 Sociolinguistic Foundations of Bilingual Education, which I have assigned every year since I started teaching the course in 1986. It always takes me right back to the University of New Mexico, summer of 1980, and your field-shaping course which opened whole new worlds to me, not just because of what you taught us, but because of who you were and are. This week, in my class, we talked about the stances on ethnicity. I told the students how you are

1 In the spoken version of this talk, a selection of photos cycling through the decades was shown on the screen as I spoke - some my own, some contributed by Fishman's family and colleagues for a slideshow originally prepared for his 80th birthday symposium at Penn in 2006 (discussed below), and others taken by my husband Steve Hornberger and students at that celebration, now almost 10 years ago. 


\begin{abstract}
known and revered in so many (in- and) out-of-the-way places around the world because of your eloquent and tireless work on behalf of separate-but-shareable ethnicities - endlessly across time and space. I think my voice betrayed my deep emotion as I read aloud to them your inspiring words: "the future of mankind, of science, or creativity and sensitivity requires learning, sharing, preserving even the most out-of-the-way languages and ethnicities because they carry within them the promise of insights, wisdoms, and alternative conceptualizations that can benefit us all" (Fishman 1982: 8).
\end{abstract}

What a wonderful gift you have given so many generations of students, scholars, and language activists, in your most remarkable life and writings. God be with you and give you peace, on this day and every day. Tukuy sunquywan 'with all my heart', Nancy. (3 October 2010)

I still have all my notes from the 1980 Summer Institute class, as well as the faded, mimeographed syllabus and extensive reading list, and especially the memories of Professor Fishman standing at the front of the enormous theatrestyle lecture hall and holding us spellbound as if we were in his living room having a private conversation with him - as he shared his wisdom of the ages and his encyclopedic knowledge on bilingual education, language and ethnicity, language planning, and the sociology of language. He had by then a couple of decades of scholarship behind him, including the Big Four Language Planning project out of the East-West Center in Hawaii with Jyotirindra Das Gupta, Björn Jernudd, and Joan Rubin in the 1960s (e. g. Fishman et al. 1968); and his roles at the Ferkauf Graduate School of Psychology, Yeshiva University beginning in the 1970s, where he served for the whole of his academic career.

During that summer course, with some trepidation, I took him up on his invitation to meet individually with him. My experience of these issues, then as now, was very much rooted in the several years I had just spent living and working in the Andes, during which I studied Quechua at the Maryknoll Instituto de Idiomas [language institute] in Cochabamba, experienced at first hand the power of Peru's (1975) language policy officializing Quechua alongside Spanish in Peru, and managed after considerable effort to get some experience working in the Cusco department of education on their new Quechua-Spanish bilingual education initiatives. I was deeply immersed in the Andean Quechua experience, which most Americans I spoke to had no inkling of at all. Much to my astonishment, Professor Fishman immediately had several apposite suggestions of texts I should consult (including Shirley Brice Heath's [1972] Telling tongues on language policy in Mexico and her chapter on Quechua and Aymara in Cooper's [1982] Language spread), as well as of people I should know, especially Catalonian-Bolivian Jesuit Xavier Albó who had at that time fairly recently emerged as Andean Indigenous language activist and sociolinguist par excellence with his (1970) Cornell Ph.D., an eminence Albó went on to occupy for all the decades since up to 
the present. This was my first experience of the vast scope and depth of Fishman's knowledge - particularly about what he often affectionately called "all those funny little languages" in every corner of the world.

Five years later, in 1985, having completed my dissertation, a pillar of which was Fishman's sociology of language (e.g. Fishman 1971, 1972), and as I was applying for academic positions, I somehow had the courage to ask him for a letter of recommendation. I still vividly remember the nervous anxiety with which I made the phone call, energetically pacing my University of WisconsinMadison Eagle Heights apartment as I spoke with him. I was later told that his letter played no small part in my getting the job at Penn - the job I still have. I was also told he described me as "indefatigable", which has undoubtedly proved to be true: I have sometimes wondered since whether he actually knew that about me (and if so, how?) or if somehow he made it happen by saying so! Fishman himself was, certainly, indefatigable.

In 1986, I traveled to Yeshiva to attend the Fifth Annual Invitational Conference: Perspectives on Bilingualism: International and Cross-Cultural Perspectives and heard such memorable speakers as Francisco Gomes de Matos on linguistic rights, François Grosjean on the bilingual as competent but specific speaker-hearer (Grosjean 1982, 1985), and Kenji Hakuta on bilingualism and cognition. Just one sample of the constellation of stellar figures Fishman inspired, mentored, prodded and celebrated over these many decades.

That same year, I was asked by my colleagues on the Penn Graduate School of Education (GSE) Sub-committee on Colloquia to invite Professor Fishman to give a talk at GSE, which I succeeded in doing - apparently after calling his office so many times that a thick trail of pink message slips greeted him in his mailbox, which he told me more or less "guilted" him into accepting. He spoke on his comparative ethnography of four New York City ethnic mother tongue schools, addressing what, with his characteristic talent for analysis and for coining new words, he called sociographic, sociolinguistic, sociopedagogic, and sociofunctional dimensions of biliteracy in English and the ethnic mother tongue, stressing overall that "biliteracy - the mastery of reading in particular, and also of writing, in two (or more) languages - is not at all a rare skill among that portion of mankind that has successfully attained literacy" (Fishman et al. 1985: 377) and that indeed understanding biliteracy might help us understand monoliteracy better which, he pointed out, American urban school systems were not having great success in teaching.

This visit ended up affording me the unforgettable experience of hosting him for a day at Penn, finding kosher food for him to eat and a quiet space for him to pray, and best of all walking around campus with him as he reminisced about his undergraduate days at Penn, 1944-1948 on a four-year Mayor's scholarship (Hornberger and Pütz 2006: 6), and how unfriendly a place it was for a Jewish 


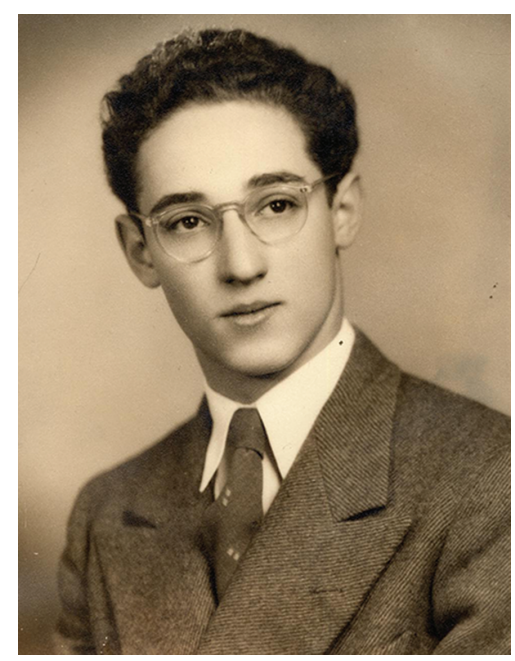

Figure 1: 1944 Joshua A. Fishman Graduation, Olney High School, Philadelphia (photo permission of Gella S. Fishman).

kid from Philadelphia. It was also then that I learned that he first taught Sociology of Language, at Penn, in 1959-1960 (Hornberger and Pütz 2006: 9) Figure 1.

In 1987, I heard Fishman's keynote at the GURT Round Table on Language Spread and Language Policy, where he asked, "what kind of language policies are helpful for all those funny little languages?”, memorably and pithily pointing out that some believe in the law of the jungle - survival of the fittest - but that interfering with/struggling against the principle of majority rule is what civilization is all about, what sociolinguistics is all about (my notes from 12 March 1987). It was a stirring talk and when I screwed up my nerve to tell him so, he graciously acknowledged my thanks, but then astonished me (again) with a self-deprecating remark about always worrying that he doesn't speak well or convincingly. This was the man whose words have touched and moved countless hundreds, thousands, even millions!

In 1988, he wrote in the Foreword for my book on Quechua language maintenance and bilingual education (Hornberger 1988) with his usual knack for getting at the heart of the issue: "The ultimate arbiter in educational decisionmaking must be an informed and concerned local community, a community that values its past, critically examines its present and carefully plans it future, combining in these plans both the local and the supra-local considerations that will inevitably influence the younger generation in its unpredictable odyssey" (Hornberger 1988: vii). The following year, Fishman set me on a path of editing volumes that would become a habit of my scholarly life, by inviting me, as he did 
so many others, to do a theme issue for the International Journal of the Sociology of Language (IJSL) - in my case, on Bilingual education and language planning in indigenous Latin America (Hornberger 1989). Over the years after founding IJSL in the 1970s, Fishman edited and oversaw publication of literally hundreds of thematic and singles issues on every conceivable language context and question, often inviting and giving voice to local and new authors no one had ever heard of and creating a huge repository of knowledge that continues to be a go-to source for in-depth treatment of the sociolinguistics of every corner of the world.

As the decades rolled on, I again invited Professor Fishman to Penn in 1992, this time as the second speaker in a new annual colloquium series we had initiated at Penn GSE honoring my colleague Nessa Wolfson in the wake of her untimely death. This series, now into its 26th year, brings to GSE a distinguished scholar in Nessa's field, TESOL and sociolinguistics - a mentor, colleague, former student, or kindred spirit whose work represents the same high standards of originality and vision as hers. Fishman amply fulfilled these criteria as a highly distinguished, founding sociolinguist who had greatly influenced Nessa.

Speaking on In praise of my language: Some components of the language nationalism belief system, he reported preliminary findings on the work he was then engaged in, work that led to his (1997) book In praise of the beloved language and that reflected continuity and development of themes in both his monumental (1966) Language loyalty in the United States and profoundly influential (1991) Reversing language shift. In that (1992) talk, he told us how

All over the world, and for many, many years, language advocates, defenders, loyalists and activists have spoken out (and written down) their views, feelings and beliefs about 'their' language [...]. I have gathered language advocacy statements by poets and by politicians, by teachers and by journalists, by scholars and by philosophers, by school children and by ordinary men and women. (Fishman 1993a: 4)

Inspecting and analyzing these statements, he identified themes of praise such as the essentiality of the traditionally associated language for ethnocultural identity, aesthetic qualities of the language, cognitive benefits of the language, implications of freedom and equality that use of the language carries with it, genius of the language, the language's link to an honorable past and hopeful future.

He defended the need to look at language consciousness, despite the (conscious or unconscious) tendency of Western researchers to look negatively on particularistic ethnolinguistic views and loyalties (Fishman 1993a: 3), and he exhorted us educators, in Philadelphia and elsewhere, to

know or suspect the existence of such views [in parents and children in our schools] in order to encounter them, in order to be able to help others strive to implement them as a 
permissible part of their identity, and in order to foster the kind of Philadelphia, the kind of Everytown and the kind of USA where such identities, and the language views they subsume, are respected and understood. (Fishman 1993a: 11)

In the ensuing years, Fishman continued to spur on my scholarly career, inviting me to contribute a chapter to his own intriguing book projects - his (1993b) book on the "First Congress" phenomenon in language planning and his (2001) book revisiting his reversing language shift framework (Hornberger 1993; Hornberger and King 2001), as well as welcoming and encouraging my own edited volume on Indigenous literacies in the Americas for his Contributions to the Sociology of Language series (Hornberger 1996). I began to think maybe he liked me, especially when he generously (and surely inaccurately) inscribed his (1999) Handbook of language and ethnic identity to me as "his most famous student"!! and signed as Joshua. It was still some years, though, before I ventured to call him Joshua or learned or knew to call him Shikl.

The next decade brought the turn of the millennium and my turn to honor Professor Fishman for all he had done for scholarship, globally, and for me, personally. In 2004 in Barcelona, I was lucky to be present as he was honored with the Linguapax Award, recognizing him for promoting peace through the respect of linguistic diversity and the promotion of plurilingual education. Elana Shohamy and Reynaldo Macías were also there - I was able to capture them in photos with Shikl and Gella Figure 2.

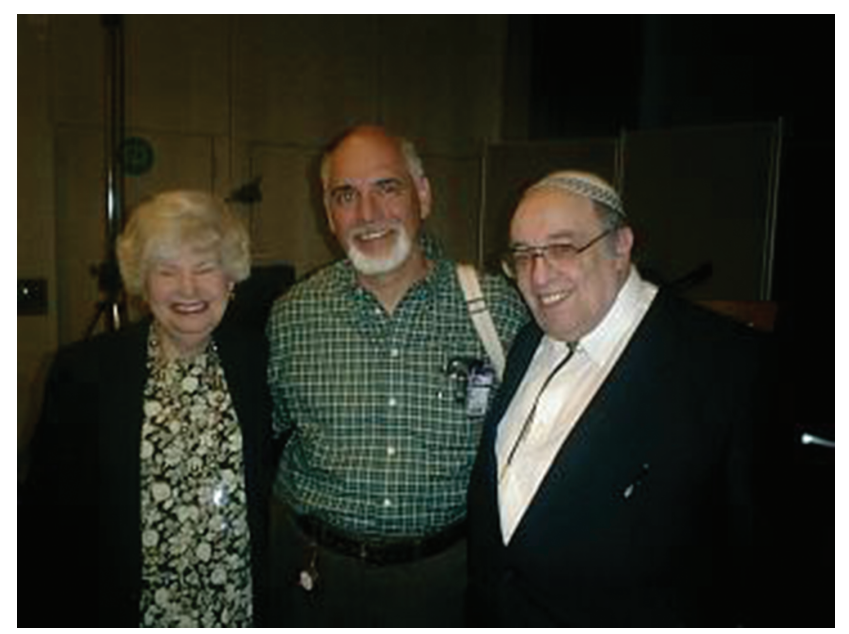

Figure 2: 2004 Gella, Reynaldo Macías, and Joshua Fishman on the occasion of Fishman's Linguapax Award, Barcelona (photo permission of Nancy H. Hornberger). 
Twice in that decade I was able to make it out to the Bronx to visit Joshua at his home - a paltry few visits when compared to my amazing colleague Ofelia García who visited Fishman almost weekly for many years. I was there once in 2005, when Martin Pütz traveled from Landau, Germany so that we could together interview Joshua for our edited volume honoring his 80th birthday; and a second time in 2008, when Shirley Heath and I took advantage of being in New York City together for a program review at Teacher's College to travel up to the Bronx for a cherished visit with Shikl and Gella Figure 3.

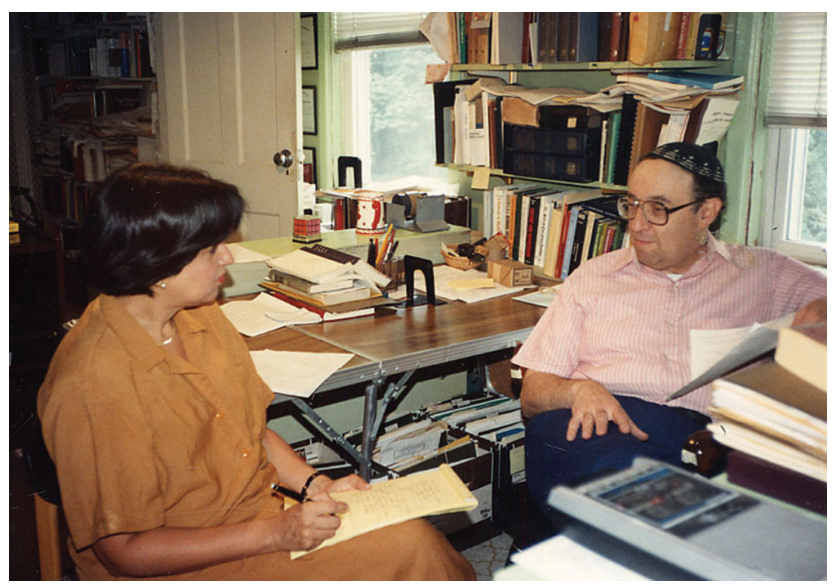

Figure 3: 1990 Joshua A. Fishman Interview with Ofelia García in home study at 3440 Bainbridge (photo permission of Gella S. Fishman).

Most memorably for me, and I believe for Shikl and Gella, in 2006, I organized an 80th birthday party for him at the University of Pennsylvania, along with a committee of Ofelia García, Rakhmiel Peltz, Martin Pütz, Harold Schiffman, and assisted by Ph.D. students Francis Hult and others of the Educational Linguistics Program including Elaine Allard, Julia Déak, Sarah Gallo, Cindy Groff, Erin Kearney, Katherine Mortimer, Shannon Sauro, Tamara Warhol, and more, all now Ph.D.s and professors in their own right who are doubtless passing Fishman's wisdom on to their own students.

The symposium was intentionally designed as an intergenerational reflection on Fishman's legacy, including speakers who with him had been in on the founding of sociolinguistics - Courtney Cazden, Shirley Brice Heath, Bill Labov, and Dell Hymes who would have been there had his health not impeded him at the last minute; a new generation of recent or emerging Ph.D.s - Francis Hult, Naomi Prawer Kadar, Shuhan Wang; and what we called an "intergenerational" group including John Baugh, Nkonko Kamwangamalu, Kendall King, and 
Stanton Wortham. Attendees represented a truly luminary and intergenerational body of scholars influenced by and paying tribute to Professor Fishman - Donna Christian, Lachman Khubchandani, Yolanda Lastra, Paul Lewis, Teresa McCarty, Mary McGroarty, Aneta Pavlenko and many, many more. Letters and narratives of congratulation flowed in from some forty or more notables who could not attend, including Robert Cooper, Shana Poplack, Robert Phillipson, Tove Skutnabb-Kangas, and Ana Celia Zentella - which you can still see at the website which Hal Schiffman has somehow miraculously kept available at http://ccat.sas.upenn.edu/plc/clpp/fishman80/ Figure 4.

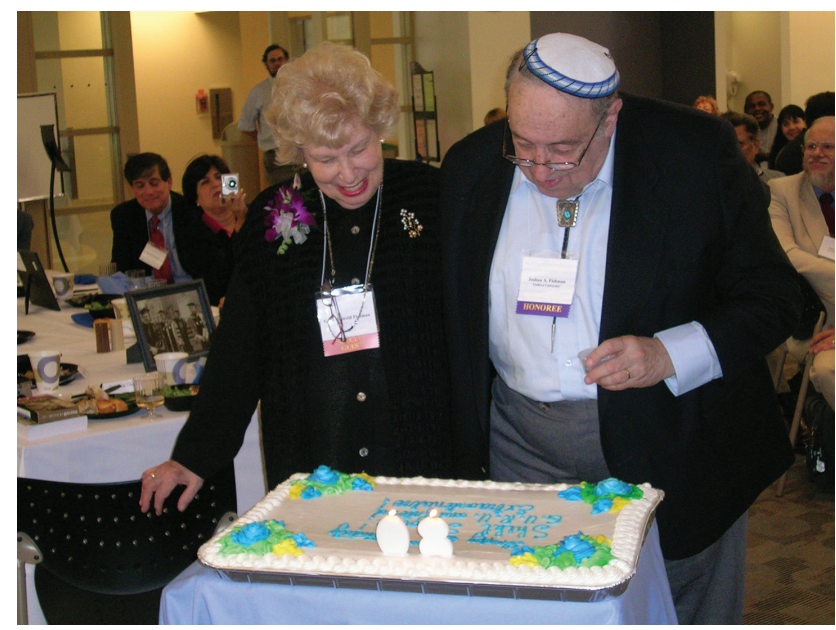

Figure 4: Fishman's 80th Birthday Symposium at University of Pennsylvania (2006): Gella and Shikl admire the birthday cake (photo permission of Martin Pütz).

It's not every scholar who is honored by not just one festschrift, but two, multivolume sets at that! In 1991, three Focusschrifts had been published on the occasion of Fishman's 65th birthday - Language and ethnicity edited by James Dow (1991), Bilingual education edited by Ofelia García (1991), and Language planning edited by David Marshall (1991), celebrated that same year at the SOL on the Horizon: Symposium on the Sociology of Language in Honor of Joshua A. Fishman's 65th Birthday, held as part of the Linguistic Society of America Summer Institute at UC Santa Cruz, California. Then, at the 2006 symposium, we presented two volumes edited in honor of his 80th birthday: Ofelia García, Rakhmiel Peltz, and Harold Schiffman (2006) edited Language loyalty, continuity and change: Joshua A. Fishman's contributions to international sociolinguistics, and Martin Pütz and I (2006) edited Language loyalty, language planning, and language revitalization: recent writings and reflections from Joshua A. Fishman. 
In our volume, Martin and I included selected gems from that (2005) interview with Shikl: about Fishman's father's and mother's birth in Moldavia and Ukraine and their arrival in America in 1910 and 1920, respectively, meeting and marrying here; about how his speaking Yiddish at age four was a "noteworthy occasion on the street[s]" of Philadelphia where he grew up (Hornberger and Pütz 2006: 5); about how he first met Gabriel Weinreich (son of Max Weinreich with whom he later studied at Columbia) when they were both counselors at a Yiddish children's summer camp in upstate New York; stories about his interactions with the likes of Weinreich, Kloss, Haugen, Gumperz, Ferguson; and some wonderfully pithy remarks like:

There's a constant argument at a high level of abstraction, which I find it hard to follow. You know, I feel like stopping after each paragraph and saying, now show me the data for that. (Hornberger and Pütz 2006: 12)

I'm willing to assume [power] is hidden, but I'm not willing to assume that it's central. Otherwise, you wouldn't have had such a dickens of a time trying to define it and make it operational. (Hornberger and Pütz 2006: 13)

If it exists, whatever you're talking about, if it exists, it exists to some degree. If it exists to some degree, then it can be measured. (Hornberger and Pütz 2006: 14)

And I remember once Ferguson said to me that he had a very deep distrust of scholars who come up with the accepted answer to a question. If there's something that you expect of a scholar, it's that he should come up with some crazy idea that ordinary people wouldn't understand. It wouldn't occur to them. In fact, you know, Jews praise various rabbinic commentators because of their abstruseness - 'who would have thought of that?' It's called distancing your thinking from common sense. (Hornberger and Pütz 2006: 22)

A high point of the 2006 Symposium was the special presentation to Shikl on behalf of the Māori people - "a gift of admiration in honour of the Rare White Heron, a rarely seen symbol of good fortune", presented in "recognition of the tremendous role he has played in guiding efforts of Māori language revitalization through the intergenerational transmission of the Māori language in families”. Toni Waho, Penelope Poutu and their daughter Hinurewa Poutu, a young kurakaupapa immersion teacher herself raised as a Māori speaker through the immersion programs her parents founded, all traveled from $\mathrm{O}$ Mana Tamariki in Aotearoa/New Zealand to present the gift.

It was truly a memorable and exhilarating day, with both Shikl and Gella participating energetically throughout. Indeed, the symposium was capped off by Professor Fishman's own concluding remarks

ranging from humorous reminiscences of birthdays past, and in particular of the difficulties of rounding up friends to celebrate a mid-July birthday as he was growing up, to comments on his current research on the historical emergence of vernacular literacies in 
Europe. As the event, and perforce his remarks, drew to a close, Fishman's parting question was whether his listeners wanted to know how to make dichotomous variables continuous - a tantalizing prospect. (Hornberger, personal communication, 19 September 2006, in email to Itzak Gottesman for publication in the Yiddish newsletter Forverts)

Fishman later wrote me on 23 December in an email titled "Time, strength, and wits": "I'm so glad I was still more or less OK during the September celebration.... Happy holidays to you and your entire crew. The world could well use a couple of million more like you-all - Joshua”.

Borrowing and recontextualizing his phrase, I conclude: The world could well use a couple of million more like Joshua Fishman!!

Acknowledgements: This paper was originally presented at the 2016 American Educational Research Association meetings in a symposium on The Life and Legacy of Joshua Fishman: Seminal Contributions to Sociolinguistics and Human Development, organized and chaired by Rosalind Horowitz and the SIG on Research in Reading and Literacy with co-sponsorship from the SIGs on Writing and Literacies, Bilingual Education Research, Second Language Research, Language and Social Processes, and AERA Division B Curriculum Studies. I am grateful to Rosalind for her vision in organizing the symposium and her kindness in inviting my participation.

\section{References}

Albó, Xavier. 1970. Social constraints on Cochabamba Quechua. Ithaca: Cornell University. Cooper, Robert. L. (ed.). 1982. Language spread: Studies in diffusion and social change. Bloomington: Indiana University Press.

Dow, James R. (ed.). 1991. Language and ethnicity: Focusschrift in honor of Joshua A. Fishman on the occasion of his 65th birthday. Philadelphia: John Benjamins.

Fishman, Joshua A. 1966. Language loyalty in the United States: The maintenance and perpetuation of non-English mother-tongues by American ethnic and religious groups. The Hague: Mouton.

Fishman, Joshua A. (ed.). 1971. Advances in the sociology of language (Volume 1, Basic concepts, theories and problems - Alternative approaches). The Hague: Mouton.

Fishman, Joshua A. (ed.). 1972. Advances in the sociology of language (Volume 2, Selected studies and applications). The Hague: Mouton.

Fishman, Joshua. 1977. Language and ethnicity. In Howard Giles (ed.), Language, ethnicity and intergroup relations, 15-57. London: Academic Press.

Fishman, Joshua A. 1982. Sociolinguistic foundations of bilingual education. The Bilingual review/La revista bilingüe 9(1). 1-35.

Fishman, Joshua A. 1991. Reversing language shift: Theoretical and empirical foundations of assistance to threatened languages. Clevedon: Multilingual Matters. 
Fishman, Joshua A. 1993a. In praise of my language. Working papers in educational linguistics 9(2). 1-11.

Fishman, Joshua A. (ed.). 1993b. The earliest stage of language planning: The "First Congress" phenomenon. Berlin: Mouton de Gruyter.

Fishman, Joshua A. 1997. In praise of the beloved language: A comparative view of positive ethnolinguistic consciousness. Berlin: Mouton de Gruyter.

Fishman, Joshua A. (ed.). 1999. Handbook of language and ethnic identity. New York: Oxford University Press.

Fishman, Joshua A. (ed.). 2001. Can threatened languages be saved? "Reversing language shift" revisited. Clevedon: Multilingual Matters.

Fishman, Joshua A., Charles A. Ferguson \& Jyotirindra Das Gupta (eds.). 1968. Language problems of developing nations. New York: Wiley and Sons.

Fishman, Joshua A., Michael H. Gertner, Esther G. Lowy \& William G. Milán (eds.). 1985. The rise and fall of the ethnic revival: Perspectives on language and ethnicity. Berlin: Mouton.

García, Ofelia (ed.). 1991. Bilingual education: Focusschrift in honor of Joshua A. Fishman on the occasion of his 65th birthday. Philadelphia: John Benjamins.

García, Ofelia, Rakhmiel Peltz \& Harold Schiffman. 2006. Language loyalty, continuity and change: Joshua A. Fishman's contributions to international sociolinguistics. Clevedon: Multilingual Matters.

Grosjean, François. 1982. Life with two languages: An introduction to bilingualism. Cambridge, MA: Harvard University Press.

Grosjean, François. 1985. The bilingual as a competent but specific speaker-hearer. Journal of Multilingual and Multicultural Development 6(6). 467-477.

Heath, Shirley Brice. 1972. Telling tongues: Language policy in Mexico: Colony to nation. New York: Teachers' College Press.

Hornberger, Nancy H. 1988. Bilingual education and language maintenance: A southern Peruvian Quechua case. Berlin: Mouton.

Hornberger, Nancy H. (ed.). 1989. Bilingual education and language planning in indigenous Latin America. International Journal of the Sociology of Language 77, entire.

Hornberger, Nancy H. 1993. The first workshop on Quechua and Aymara writing. In Joshua A. Fishman (ed.), The earliest stage of language planning: The "First Congress" phenomenon, 233-256. Berlin: de Gruyter.

Hornberger, Nancy H. (ed.). 1996. Indigenous literacies in the Americas: Language planning from the bottom up. Berlin: Mouton.

Hornberger, Nancy H. \& Kendall A. King. 2001. Reversing Quechua language shift in South America. In Joshua A. Fishman (ed.), Can threatened languages be saved? "Reversing language shift" revisited: A 21st century perspective, 166-194. Clevedon: Multilingual Matters.

Hornberger, Nancy H. \& Martin Pütz (eds.). 2006. Language loyalty, language planning, and language revitalization: Recent writings and reflections from Joshua A. Fishman. Clevedon: Multilingual Matters.

Ibrahim, Awad. Forthcoming. Immigration/flow, hybridity and language awareness. In Jasone Cenoz, Durk Gorter \& Stephen A. May (eds.), Encyclopedia of language and education (Volume 6L, Language Awareness and Multilingualism). New York: Springer.

Marshall, David (ed.). 1991. Language planning: Focusschrift in honor of Joshua A. Fishman. Philadelphia: John Benjamins Publishers.k

Peru 1975. Decree Law 21156. Lima, Peru, May 27. 